\title{
УДК 340.152
}

DOI https://doi.org/10.32837/npnuola.v28i0.697

\section{Л. Я. Коритко, В. О. Джуган}

\section{ОСНОВНІ РИСИ ПРАВА СТАРОДАВНІХ ІНДІЇ ТА КИТАЮ}

Усі держави Стародавнього світу мають власну історію виникнення та розвитку. Найчастіше науковці виділяють Європейський та Східний (Азійський) шляхи виникнення таких держав. Так, Індія та Китай мають Східний шлях їх виникнення. За формою держави ці країни були Давньосхідними деспотіями з абсолютною владою правителя, централізованим державним апаратом із суворим тоталітарним режимом та чітким наглядом за підданими, тісно консолідованою світською та духовною владою правителя та вищих чиновників, узвичаєним застосуванням обмеження прав і свобод людей. Але в кожній державі така деспотія мала свої особливості. Зокрема, Стародавня Індія була монархією, яка відрізнялася від типової рабовласницької деспотії: в складі Індії постійно була низка автономних утворень, які мали свої органи управління та звичаї, допускалися різні думки, центральний апарат був помітно слабшим, ніж у інших держав, походження влади було не таке сакралізоване, а також існували дорадчі органи. А от Стародавній Китай був яскравим прикладом Східної деспотії, тобто абсолютною теократичною монархією, якою керував цар. Цар-правитель одночасно очолював військово-бюрократичний апарат, призначав чиновників центрального та місцевого рівня, він був верховним жерцем, вищим суддею та першим організатором господарства. Імперські чиновники були під строгим контролем центральної влади, їх посади переходили в спадок, але з дозволу царя. Паралельно з розвитком держави розвивалося і право. Право відображало суть і функції певної держави та безпосередньо відбивало форму держави, іiі державницьку позицію, соціальний порядок та суспільний устрій. На основі вищезазначених положень державної організації Стародавній Індії та Китаю була вибудована і їх система права, загальні риси якої збереглися й сьогодні.

Питання історії держави і права країн Стародавнього Сходу досліджували такі науковці, як: Н.В. Аніщук, О.М. Бандурка, Л.М. Бостан, С.К. Бостан, А.В. Грубінко, Є.С. Дурнов, О.В. Кузьминець, С.В. Кульчицький, І.Д. Мудрак, О.В. Горяга, М.І. Настюк, В.І. Орленко, О.О. Орлова, Ю.В. Сокур, О.В. Талдикін, Б.Й. Тищик, А.П. Хома, О.О. Шевченко, Я.В. Шевчук-Бела та інші. Дослідження державно-правового розвитку Стародавньої Індії та Стародавнього Китаю здійснювали: М.М. Бедрій, 
В.Д. Гапотій, А.М. Завальний, А.П. Заєць, Д.Г. Каюк, І.М. Коваль, Є.О. Куйбіда, А.А. Музика, Я.В. Попенко, В.М. Пуйко, О.С. Рождественська, Є.С. Логвиненко, І.А. Логвиненко тощо. Однак уже понад сотню років науковці на основі історико-правових матеріалів прагнуть відтворити історію держави та права цих країн, але немає єдиної думки з приводу того, як відбувалося державотворення і правотворення, тому вивчення цього питання $є$ важливим, а питання основних рис права цих країн залишається актуальним.

Ця стаття присвячена з'ясуванню сутності та змісту основних рис права Стародавніх Індії та Китаю. Зазначена мета зумовила такі завдання цієї роботи: вказати періоди розвитку держави та права Стародавніх Індії та Китаю, дослідити риси права Стародавньої Індії; з'ясувати риси права Стародавнього Китаю та зробити відповідні висновки.

Періодизація історії розвитку держави в Стародавній Індії включає чотири періоди: 1) Індський (Харапський, Доведійський) (XXIII-XVIII ст. до н.е.); 2) Ведійський (XIII-VII ст.ст. до н.е.); 3) Буддійський (VI-III ст.ст. до н.е.); 4) Класичний (II ст. до н. е. - V ст. н. е.) [1, с. 64]. Історія розвитку держави в Стародавньому Китаї включає охоплює чотири періоди: 1) Період Трьох династій (Династія Ся (XXIII-XVIII ст. до н.е.), Династія Шань-Iнь (XVIII-XII ст. до н.е.), Династія Чжоу (XII-III ст. до н.е.); 2) Період імперії Цінь (221-206 рр. до н.е.); 3) Період імперії Хань (Західна Хань (206 р. до н.е. -25 р. н.е.); Східна Хань (25-220 рр. н.е.) [2, с. 43].

Основу соціальної структури Стародавньої Індії становила община. Суспільство поділялося на варни (замкнені групи): I - брахмани (двічі народжені), це була найвища варна (жерці, священнослужителі); II були кшатрії (двічі народжені) - світська знать; III-ю - вайші (селяни, ремісники, торговці); IV-ю - шудри, які були особисто вільними та служили вищим варнам. Найнебезпечніше становище займали чандали і парії (позаварнові), які вважалися покидьками суспільства і виконували найбрудніші, принизливі роботи. Вони жили за межею поселення чи міста. В Стародавній Індії існував інститут рабства, джерелом якого були війни, злочинці та боржники. Суспільний лад Стародавнього Китаю був сформований у три соціальні групи, такі як: 1 (а) - привілейована родова аристократія (правитель, його родина, наближені, жерці, чиновники, знать захоплених племен); 2 (б) - вільні селяни - общинники; 3 (в) - раби, які перебували у становищі тварини.

Форма досліджуваних рабовласницьких держав по своїй суті була політичною організацією влади рабовласників, створена для реалізації їх абсолютної диктатури та повновладдя над рабами, а також здійснення безконтрольних функцій щодо інших категорій населення. Право в Стародавніх Індії та Китаї було спрямоване на захист інтересів рабовласників та знаті, а також на обмеження прав і свобод інших груп людей. Водночас джерела права країн Стародавнього Сходу свідчать про досить високий рівень розвитку правової думки. Так, джерелами права Стародавньої Індії були: звичаї, Закони Ману, Дхамашастра, Архашастра, нарада та веди, а до джерел права Стародавнього Китаю належали: звичаї, «Книга законів Царства Вей», розпорядження імператорів. Джерела права містили правила поведінки відразу різних галузей права. 
Слід також виділити основні риси права країн Стародавнього Сходу. На думку А.В. Грубінко, до них належали: кастово-становий характер (фіксувало соціальну нерівність, ієрархію станів і суспільних верств зі своїм окремим правовим статусом та мало рабовласницький характер); синкретичність (воно було нерозривно пов'язане з етичними нормами, а правова норма мала релігійне обгрунтування); традиційність (основним джерелом їх права впродовж століть залишалися звичаї, а правові системи давньосхідних суспільств часто відображали норми старого родового ладу (колективна відповідальність членів сім’і або всіх общинників за провину, здійснену одним із них, кровна помста, самосуд, таліон, принижене становище жінок, дітей в патріархальній сім’ї тощо); консерватизм (несприйняття нововведень у системі правовідносин); казуїстичність (фіксувалася не в абстрактній формі, а у вигляді конкретного випадку із суспільних відносин і практики державного управління); незавершеність (неповнота, нерозробленість цілої низки інститутів і норм, відсутність поділу на галузі права); формалізм (дотримання зовнішньої форми в оформленні нормативних актів, текст яких мав пафосний характер із значним релігійним підгрунтям; виклад правових норм відповідав певним релігійним концепціям) [3, с. 32]. Бостан Л.М. та Бостан С.К. як окремі риси виділяють: нерівність прав чоловіків та жінок у сімейному та спадковому праві; невідмежованість злочинів від приватних правопорушень [4, с. 53].

У Стародавній Індії розуміння права як сукупності самостійних норм, що регулюють суспільні відносини, було невідоме. Відносини регулювалися більше етичними правилами, ніж правовими, та мали тісне поєднання 3 релігійними віруваннями [5, с. $15 ; 6$, с. 88]. Вони називалися дхарми і містилися у збірниках - дхармашастрах. Найвідомішим збірником релігійних, моральних і правових настанов (із таких дхармашастр) були Закони Ману (II ст. до н.е. - II ст. н.е.) [7, с. 19-24], укладення якого пов'язують 3 іменем міфічного пращура людей - Ману. Цей документ мав 12 глав, кожна 3 яких містить велику кількість статей (2 685), написаних у вигляді ритмічної прози. Закони Ману в Індії не були обов'язковими до виконання, мали рекомендаційний характер і містили норми, на які спиралося все індійське суспільство. Другий трактат Артхашастра Каутільї про мистецтво політики й управління державою (I ст. до н.е. - I ст. н.е.) належить Каутільї раднику царя Чандрагупти із династії Маур'їв (IV - II ст.ст. до н.е.).

Науковці та джерела вказують, що в період створення Законів Ману в Індії існувало право власності, всі добре розуміли різницю між власністю та володінням, особливо охоронялася приватна власність. Серед основних видів власності називають право власності на землю. Земельний фонд держави складали землі володаря, общинні і приватні землі [8, с. 84]. Правомірними способами набуття нерухомої власності були: спадщина, купівля, одержання дарунку та набувальна давність. Якщо власник «мовчки спостерігає», як хтось користується його власністю упродовж 10 років, то право отримання ї̈ назад втрачається (VIII, 147). Набуття рухомої власності можливе також, крім названих казусів, через знахідку, здобич, позичку під відсотки, за виконання роботи. Виморочне майно представників трьох нижчих варн переходило у власність царя (IX, 189) [9, с. 11]. 
Зобов'язальне давньоіндійське право (Закони Ману) передбачало можливість укладення таких видів договорів: купівлі-продажу; позики; оренди; особистого наймання; перевезення та дарування [5, с. 92].

Закони Ману містили норми спадкового права. В Індії не було спадкування за заповітом. За законом спадкували лише сини - порівну, а дочкам обов'язково виділявся посаг. Спадщина матері ділилася на всіх дітей. У спадкуванні також мала значення належність до варни. Наприклад, якщо брахман мав дітей від кількох дружин, які належали до різних варн, то син брахманки одержував 4 частки, син кшатрійки - 3 частки, син вайшійки -2 частки, а син шудрянки -1 частку $[9$, с. 11].

Закони Індії мали детальні норми сімейного права. 3 одного боку, в Законах Ману жінка-мати мала важливе значення, а з іншого - класове суспільство, приватна власність погіршила становище жінки. Шлюбний вік для чоловіків у Індії наступав із 20 років, для дівчат - із 12 і навіть молодше. Шлюб в Індії був своєрідною угодою, внаслідок якої чоловік купував собі дружину, і вона ставала його власністю. Дружина мала поважати свого чоловіка, беззаперечно виконувати його волю. Ні молоді, ні літні жінки нічого не повинні робити за власною волею, навіть у своєму будинку. Жінка повністю залежала від свого чоловіка і синів - у дитинстві вона мала бути під владою батька, в молодості - чоловіка, а після його смерті - синів (жінка не спроможна до самостійного життя) $(\mathrm{V}, 147$, 148). Дружина не могла залишити чоловіка за жодних обставин; навіть у разі ії продажу, залишення чоловіком чи смерті. Дружина служить чоловікові і на землі, і на небі. Найгіршим для індійської жінки в усі часи було залишитися вдовою. Для неї був неможливий повторний шлюб, адже «інший чоловік ніде не передбачений для доброчесних жінок» $(\mathrm{V}, 162)$ $[10$, c. 74,67$]$. Розлучення з боку чоловіка було відносно вільним, особливо коли дружина мала свої вади: страждала безпліддям, іншою тяжкою хворобою, виявляла грубість до чоловіка. У такому разі чоловік міг привести до свого будинку іншу дружину.

За Законами Ману кримінальне право, з одного боку, характеризувалося досить високим рівнем розвитку, що проявлялося у вказівках на форми вини (намір і необережність), рецидив, співучасть, тяжкість злочину залежно від приналежності потерпілого і винного до певної варни, а з іншого боку - Закони Ману відображають збереження старовинних пережитків, про що свідчать збереження принцип таліона, ордалії, відповідальність общини за злочин, скоєний на іiі території, якщо злочинець невідомий $[8$, с. $86-77 ; 6$, с. 95$]$.

3-поміж злочинів Закони Ману вирізняють: державні злочини (перехід на бік ворогів царя, псування міських воріт); майнові злочини (крадіжка і пограбування); злочини проти життя та здоров'я (вбивство, тілесні ушкодження, що відносилися до образи дією); злочини проти моралі, сім'ї та шлюбу (перелюбство дружини, згвалтування, розмова чоловіка з чужою дружиною віч-на-віч). Система покарань у Стародавній Індії мала такий вигляд: кваліфікована смертна кара, проста смертна кара (утоплення), гоління голови для брахмана прирівнювалося до смертної кари, членоушкоджувальні покарання; штрафи; вигнання із країни брахмана з усім його 
майном; тюремне ув'язнення; таврування; перетворення на раба [2, с. 41]. В Законах Ману заслуговує на увагу той факт, що був порядок, черговість застосування покарань: «Спочатку слід зробити зауваження, після нього догану, штраф, а після після цього вище - тілесне покарання» (ст. 129, VIII). Але в разі необхідності можна одночасно накласти всі названі покарання (ст. 130, VIII) [12, с. 126].

Праву Стародавнього Китаю характерні такі риси: воно не піддалося впливу жодної світовій релігії, не виникало з «божественного промислу», проте воля Неба знаходила своє вираження в обранні Небом правителя, наданні йому права керування. Покарання і нагородження призначалися правителем, який діяв на підставі закону, створеного ним або з його волі; традиційне право Китаю розвивалося передусім як кримінальне право, норми якого урегульовували майнові, сімейні, управлінські правовідносини для взаємодії та правопорядку. Тому право розглядалося через природу та сенс покарання. Покарання розумілося як кара за вчинений злочин, за своєю тяжкістю воно повинно відповідати тяжкості проступку, як і нагорода - заслузі, що покликане застерегти й усунути потенційних злочинців.

До джерел давньокитайського права належали: моральні норми, судова практика, звичаї, закони правителя («Книга законів царства Вей»), розпорядження імператорів.

Право власності в Китаї на землю в період Інь належало вану, його наближені отримували право користування земельними наділами; у період Чжоу з'являється право приватної власності на землю; у період Цинь (середина I ст. до н.е.) приватна власність на землю зміцнюється та поширюються торгові операції із землею. У період Інь раби не перебували у власності господаря, а вважалися власністю держави, колективу. Обмін і купівля рабів стали можливими лише в період Чжоу. У V-III ст.ст. до н.е. існували вже дві категорії рабів: приватні і державні. У період Цинь дозволялося вільно ними торгувати.

Зобов'язальне право Стародавнього Китаю передбачало договори: міни; купівлі-продажу; дарування (землі, рабів, зброї тощо); позики (боржник, що вчасно не повертав позику, ставав рабом); оренди землі; особистого найму [6, с. 128].

Спадковим правом передбачено, що майно батька успадковував його старший син від першої дружини. Якщо синів не було, то до успадкування залучалися інші родичі дружини. Дружина мала право на успадкування, але воно було істотно обмеженим.

У сімейному праві Стародавнього Китаю шлюб від імені дітей укладали батьки. Чоловік та батько мав беззаперечний авторитет. Заміжня дружина не мала права на особисте майно, а укладаючи шлюб, вона розривала зв'язки зі попередньою родиною. Давньокитайське право надавало значну кількість привілеїв для чоловіка і забороняло їх для жінки. У будинках китайської аристократії значного поширення набули гареми з рабинями-наложницями [2, с. 51].

Право Стародавнього Китаю - це передусім кримінальне право, у якому найважливіше значення має Карне уложення Тан - “Тан люй шу i”, що зосередило всю філософію права Китаю. 
Законодавством Китаю були передбачені злочини проти: держави (зрада імператору, бунт, змова, зберігання забороненої конфуціанської літератури); релігії (чаклунство, висипання попелу на вулицю); особи (вбивство, завдання тілесних ушкоджень); порядку управління (помилка чи проступок чиновника під час виконання службових обов'язків, недонесення чиновника про протиправні діяння свого колеги) та військові злочини (дезертирство). Їх було надзвичайно багато. В епоху Чжоу законодавець знав більш ніж 500 різноманітних злочинів [2, с. 51-52].

У системі покарань вживався термін "бао", що означав відплату за вчинений злочин. У додержавний період застосовувалася кровна помста, а 3 появою державної влади кримінальне переслідування мало свої акценти. Крайня жорстокість запанувала в епоху Цинь, злочинців варили в казані, виривали у них ребра, просвердлювали голову. За державні злочини знищували не лише самих злочинців, а й три покоління його родичів по лінії батька, матері і дружини. Основною метою покарання було залякування. Давньокитайське право знаходило витончені покарання, а саме: смертна кара в різних формах (підсмажування на вогні, розрубування на дрібні шматочки, закопування живцем у землю); членоушкоджувальні покарання (відрізання вух, носа, відрубання руки, ноги, виколювання очей тощо); штрафи, ними дозволялося відкуповуватися від покарання; тюремне ув'язнення; знеславлюючі покарання (нанесення фарби на обличчя, татуювання винного). Смертна кара була як простою (відрубування голови, удушення), так і кваліфікованою (четвертування, розрубування навпіл, закопування живим у землю, виламування ребер). У систему покарань Стародавнього Китаю було закладено принцип колективної відповідальності, який згодом поширився на вільне населення, зокрема на чиновників [13, с. 92-93]

На основі проведеного дослідження можна зробити такі висновки: періодизація державогенезу та правогенезу Стародавніх Індіï та Китаю практично збіга.ться та охоплює в Індії: Індський, Ведійський, Буддійський, Класичний періоди, а в Китаї: Період Трьох династій, Період імперії Цінь, Період імперії Хань. У цих державах було право власності, зобов'язальне право, сімейне право, спадкове та кримінальне право. Кримінальне право було комплексним, а в Стародавньому Китаї воно регулювало майнові, сімейні, управлінські правовідносини людей для досягнення правопорядку. У Стародавній Індії та Китаї не було сформованої системи права, але певні елементи системи права в ньому були: норми, окремі інститути, елементи деяких підгалузей, окремих чисто самостійних галузей не було, бо вони були змішаними. Найбільш розвиненим було кримінальне право, яке містило норми різних галузей права та включало розширену систему покарань, які характеризувалися особливою жорстокістю.

\section{Література}

1. Хома Н.M. Історія держави та права зарубіжний країн: навчальний посібник для студентів вищих закладів освіти. 3-тє вид., стереотипне. Львів: Новий Світ-2000, 2008. 480 с.

2. Кузьминець О.В., Дурнов Є.С., Сокур Ю.В. Історія держави і права зарубіжних країн (схеми, коментарі, термінологічний словник): навчальний посібник. К.: Центр учбової літератури, 2012. 242 с. 
3. Грубінко А.В. Історія держави i права зарубіжних країн: навчальний посібник. Тернопіль: Навчальна книга - Богдан, 2010. 392 с.

4. Бостан Л.М., Бостан С.К. Історія держави і права зарубіжних країн: Навчальний посібник. 2-е вид. перероб. й доп. К.: Центр учбової літератури, 2008. 730 с.

5. Мудрак І. Д. Історія держави і права зарубіжних країн: Курс лекцій. Ірпінь: Державна податкова адміністрація України; АДПСУ 2001. 232 с.

6. Гапотій В.Д., Куйбіда Є.О., Попенко Я.В. Історія держави і права зарубіжних країн (Стародавній світ та доба Середньовіччя): підручник. Мелітополь: Видавництво МДПУ ім. Б. Хмельницького, 2015. 603 с.

7. Історія держави і права зарубіжних країн: правові джерела: навчальний посібник посібник / Упоряд. Г.І. Трофанчук. К.: Юрінком Інтер, 2008. 352 с.

8. Бандурка О.М. Історія держави і права зарубіжних країн: підручник. Харків: Майдан, 2020. 618 c.

9. Макарчук В.С. Загальна історія держави і права зарубіжних країн: навчальний посібник. Ірпінь: ДПА України, 2001. 232 с.

10. Рождественська О.С. Закони Ману та соціально-правове становище жінки у сучасній Індії. Вісник Харківського національного університету імені В.Н. Каразіна. 2012. № 12 (1028). C. 64-68.

11. Джужа О.М. та інші. Історія держави і права зарубіжних країн: навчальний посібник. K.: HABC, 2012. 375 c.

12. Логвиненко Є.С., Логвиненко І.А. Тілесні покарання у Стародавній Індії: історико-правовий аналіз. Правоохоронна функиія держави: теоретико-методологічні та історико-правові проблеми дослідження: Матеріали міжнародної науково-практичної конференції, 17 травня 2019 р. Харків: ХНУВС, 2019. 292 с.

13. Логвиненко Є.С, Логвиненко I.А. Покарання в праві держав Стародавнього світу: монографія. Харків: ФОП Панов А.П., 2019. 252 с.

\section{Ано т а ц і я \\ КориткоЛ.Я., Джуган В.О. Основні риси права Стародавніх Індії та} Китаю. - Стаття.

Кожна держава Стародавнього Світу має свою історію виникнення та розвитку. Ці держави були східними деспотіями зі своїми особливостями. Стародавня Індія як монархія мала окремі демократичні інститути, а Стародавній Китай був абсолютною теократичною монархією. Право в них захищало інтереси рабовласників, знаті та обмежувало права інших людей. Джерелами староіндійського права були звичаї, закони Ману, Дхамашастра, Архашастра, нарада, веди; давньокитайського - звичаї, Книга законів Царства Вей, розпорядження імператорів. Основними рисами права країн Стародавнього Сходу були: кастово-становий характер, дискретичність, традиційність, консерватизм, казуїстичність, незавершеність, формалізм.

В Стародавній Індії виділялося право: а) власності (наприклад, на землю; земельний фонд складався з земель: володаря, общинних, приватних); способами набуття права власності були: спадкування, купівля, дарунок, знахідка, здоби, набувальна давність; б) зобов'язальне (купівля-продаж, позика, оренда, особистий найм, перевезення, зберігання, дарування; в) сімейне (шлюб був обов'язком для продовження роду, а вибір обранців покладався на батьків); г) спадкове виникало за законом у синів, а дочкам виділявся посаг; д) кримінальне включало нові інститути (вина, рецидив, співучасть) та пережитки первісного суспільства (принцип таліону, ордалії). Злочини були: державні, релігійні, проти особи, проти власності, проти сім'ї; до покарань належали: тілесні, смерна кара, членоушкодження, штраф, вигнання, таврування, усунення з посади.

В Стародавньому Китаї виділялося право: 1) власності (на землю та на рабів. Землі були в державній та приватній власності); 2) зобов'язальне (міна, купівля-продаж, дарування, позика, оренда землі, особистий найм); 3) спадкове (за законом та передбачало спадкування майна батька старшим сином від першої дружини); 4) сімейне (передбачало укладення шлюбу батьками від імені дітей та категоричний авторитет батька в сім'ї); 5) кримінальне (передбачало злочини проти: держави, релігії, особи, порядку управління та військові злочини; до покарань належали: смертна кара, членоушкодження, штрафи, тюремне ув'язнення та знеславлюючі покарання). 
У цих державах право було безсистемним, але окремі іiі елементи були (норми, певні інститути, елементи підгалузей), самостійних галузей не було, бо вони були змішаними. Кримінальне право було об'ємним та містило норми різних галузей права.

Ключові слова: джерела права, право власності, зобов'язальне право, спадкове право, кримінальне право, покарання, елементи системи права.

\section{$\mathrm{S} \mathbf{u} \mathrm{m} \mathrm{m}$ a $\mathrm{r} \mathbf{y}$}

Korytko L. Ya., Dzhuhan V. O. The main features of the law of Ancient India and China. - Article.

Each state of the Ancient World has its own history of origin and development. These states were eastern despots with their own characteristics. Ancient India as a monarchy had separate democratic institutions, and Ancient China was an absolute theocratic monarchy. The law in them protected the interests of slaveholders, the nobility and limited the rights of others. The sources of ancient Indian law were the customs, laws of Manu, Dhamashastra, Arhashastra, meeting, Vedas; ancient Chinese - customs, the Book of Laws of the Wei Kingdom, the orders of emperors. The main features of the law of the countries of the Ancient East were: estate-class character, discretion, traditionalism, conservatism, casuistry, incompleteness, formalism.

In Ancient India, the right was allocated: a) ownership (for example, land; the land fund consisted of land: the owner, communal, private); ways of acquiring property rights were: inheritance, purchase, gift, discovery, muffin, acquisitive prescription; b) mandatory (sale, loan, lease, personal hire, transportation, storage, donation; c) family (marriage was a duty to procreate, and the choice of the elect was entrusted to the parents); d) hereditary arose by law from sons, and daughters were given a dowry; e) criminal included new institutions (guilt, recidivism, complicity) and remnants of primitive society (the principle of talion, ordeal). The crimes were: state, religious, against the person, against property, against the family; punishments included: corporal punishment, death penalty, mutilation, fine, expulsion, branding, removal from office.

In ancient China, the right was allocated: 1) ownership (of land and slaves. Land was in public and private ownership); 2) obligatory (exchange, purchase and sale, gift, loan, land lease, personal hire); 3) hereditary (by law and provided for the inheritance of the father's property by the eldest son from the first wife); 4) family (provided for the marriage of parents on behalf of children and the categorical authority of the father in the family); 5) criminal (provided for crimes against: the state, religion, persons, government and war crimes; punishments included: the death penalty, mutilation, fines, imprisonment and disgraceful punishments).

In these states, law was unsystematic, but some of its elements were (norms, certain institutions, elements of subsectors), there were no independent branches, because they were mixed. Criminal law was voluminous and contained rules of various branches of law.

Key words: sources of law, property law, contract law, inheritance law, criminal law, punishment, elements of the legal system. 